$\begin{array}{cc}\text { Türk Coğrafya Dergisi } \\ \text { Basılı ISSN 1302-5856 } & \text { Turkish Geographical Review } \\ & \text { www.tcd.org.tr }\end{array}$

\title{
Kavramsal ve tarihsel açıdan askeri coğrafya: Coğrafya mı? Jeopolitik mi?
}

\section{Military geography in conceptual and historical terms: Geography or geopolitics?}

\author{
Kaan Kapan a* (D) Ömer Emre Kuşcu b \\ a Istanbul Üniversitesi, Edebiyat Fakültesi, Coğrafya Bölümü, Istanbul, Türkiye. \\ ${ }^{b}$ Istanbul Üniversitesi, Sosyal Bilimler Enstitüsü, Coğrafya Bölümü, İstanbul, Türkiye.
}

ORCID: K.K. 0000-0003-2979-5057; Ö.E.K. 0000-0001-9733-1612

\section{BILGI / INFO}

Geliş/Received: 08.10.2021

Kabul/Accepted: 07.12.2021

\section{Anahtar Kelimeler:}

Coğrafya

Jeopolitik

Askeri coğrafya

Siyasi coğrafya

Askeri strateji

Keywords:

Geography

Geopolitics

Military geography

Political geography

Military strategy

*Sorumlu yazar/Corresponding author:

(K.Kapan) kaan.kapan@istanbul.edu.tr

DOI: $10.17211 /$ tcd.1006406

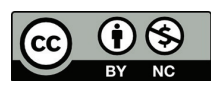

\section{Athf/Citation:}

Kapan, K., \& Kuş̧̧u, Ö. E. (2021). Kavramsal ve tarihsel açıdan askeri coğrafya: Coğrafya mı? Jeopolitik mi? Türk Coğrafya Dergisi, (78), 145-154.

https://doi.org/10.17211/tcd.1006406

\begin{abstract}
ÖZ / ABSTRACT
Geçmişten günümüze gerçekleşen tüm askeri faaliyetlerde saha ve masada güçlü olanın, dönem şartları gereği birçok ulusal ve uluslararası arenada başarılı çalışmalar yapabildiği görülmüştür. Ancak günümüz şartlarında askerî açıdan bir bölgenin fiziki coğrafyasına dayalı unsurların bilinmesinin yanında bölgenin beşerî özelliklerinin de detaylı bir şekilde analiz edilmesiyle başarılara ulaşılabilmektedir. Kısacası olumlu askeri çıkarımlar elde etmek arttk eskide olduğu gibi sadece fiziki şartların bilinmesine ya da harp ve masa gücüne bağıı olmadığı açıkça görülebilmektedir. Özellikle 1900 'lü yıllardan sonra meydana gelen teknolojik gelişmeler ve küreselleşmenin hızlanmasıyla birlikte askeri planlamaların ve savaş türlerinin çeşitlilik kazandığı bilinmektedir. Çeşitlilik sonrasında bu alandaki çalışmaların sadece askerler tarafindan değil sivil uzmanlarla birlikte çeşitli çalışmaların yürütüldügü ve yürütülmesi gerekliliği anlaşılmıştır. Bu çalışmayla Türkiye'de coğrafyacılar tarafindan uzun süre ihmal edilmiş olan askeri coğrafyanın tanımı, kapsamı, inceleme alanı, sınırlıııları ve amacını ortaya koyup sonrasında geçmiş ile günümüz tutum farklılıklarının karşılaştırmasını yaparak alana temel nitelikte bir yayım ortaya çıkarmayı hedeflemiş bulunmaktayız. Askeri coğrafyanın bir inceleme alanı olarak bilimsel temellerinin atıldığı 19.yüzyıl Avrupa literatüründen başlanarak Osmanlı Dönemi ve Cumhuriyet yıllarından da çalışmalar incelenmiş ve günümüze kadar çeşitli görüşlerle irdelenen askeri coğrafya çalışmalarına yer verilmiştir. Tarihsel gelişim sürecine dayanarak izah edilmeye çalışılan askeri coğrafyanın geçmişi, bugünü ve geleceği hakkında bir perspektif sunulması amaçlanmıştır.
\end{abstract}

Throughout history it has been observed that those who have got strength on the table and in the field have been successful in both national and international arena in accordance with the historical context. However, it is currently a must to know the human characteristics of a region along with various characteristics related to its physical geography in order to be successful in military sense. In short, it is now an already known or observed fact that drawing certain conclusions leading to military success is not possible only through the knowledge of physical conditions or strategic and military power in the field as it has been before. Types of war and military planning have increased with technological advance and globalization particularly after the 1900s. This variety revealed the necessity to conduct research in this field not only by soldiers but also in cooperation with civilian experts.

This study therefore aims to contribute to literature in this field by examining the definition, scope, research area, limitations and purpose of military geography; and thereby making a comparison between past and current approaches to it through a civilian lens.

\section{Extended Abstract Introduction}

This study starts with the revelation of the definition, scope and purpose of military geography and an analysis of its situation in both national and international literatures throughout history. Practical differences and changes in the field of military geography have been determined and it has been concluded that military geography is in fact a sub-discipline of geography in general in the world. However, it has been revealed that it is necessary to conduct multidisciplinary studies in this field in order to prevent any deficiencies.

\section{Data and method}

Based on the related studies and examples, it is obvious that military geography has changed to a significant extent from past to the present. Especially in the periods when there were rapid 
industrialization and urbanization, battles and conflicts diversified. The effects of globalization on all geographies since the early 20th century required a re-evaluation of military approaches and the concept of security in terms of military geography. A review of all positive and negative effects of both human and physical geographies on military activities in both times of war and peace within the scope of time and space has increasingly becoming significant. This historical development and change have made the definition of military geography, those who should deal with it, and the differences between past and present in these senses, debatable issues. The main reasons for the fact that there has not been a global consensus even about the definition of military geography, are lack of efficient studies conducted by civilian experts or joint studies conducted by military and civilian experts, and the instability in conditions. This also reveals that there is a strong need for comprehensive research on the geographical sub-discipline in question.

In today's world where military boundaries have disappeared and strategic areas and cities have become open targets, the significance of military geography as a sub-discipline will no doubt increase with the increasing use of technology in this field. As a result of all these developments, a need for a detailed examination and technological processing of human and physical characteristics of military geography for a specific area has emerged. Military geography first emerged in Europe in the 18th century as a field of study and its major purpose was to use geographical factors facilitating the military seizure of an area. Even though a number of states continued their studies in this field for varying purposes, the understanding that a country's expansion in terms of its boundaries emerged especially as a result of Germany's expansionist attitude during World War II is a natural course of development and the understanding of organic state have kept geopolitical and military geography in the background, even caused studies related to them to be forbidden. Whereas military geography had been neglected on the grounds that it provided a basis for countries' expansionist attitudes in the past, technological developments, update of global weapons and diversification of threats brought military geography to the foreground again.

\section{Results and discussion}

Military activities today seem to require in-depth geographical information. Upon re-popularization of sovereignty based on geographical space and region, military geography as a more comprehensive and profound discipline has attracted attention. Former researches on military geography in national literature have been made by military experts for years. However, it was later determined that there was a need for civilian expertise since the said discipline lacked certain geographical fundamentals. In short, not only military leaders and experts but also civilian geographers should deal with "spatiality of militarism" as it has been abroad for a long time. It is almost impossible to observe and analyze technical factors which are of great significance in military discipline such as economy, industry, geographical information systems, air photography along with the social structure and culture of people residing in a certain region from a single and limited angle. Handled either geographically or geopolitically, it is a discipline which should be expanded for national benefits. As a consequence, military geography is a research area the significance of whi- ch should not be underestimated in terms of increasing the country's strength and preserving its existing sources.

\section{Giriş}

Askerî harekâtların günümüzden ne kadar eskiye gidilirse gidilsin her dönemde bir mekân üzerinde veya bir mekân için (soğuk/sıcak savaş türlerinde) gerçekleştirildiği bilinmektedir. Uğrunda savaşılan ya da askeri faaliyetler yürütülen bu ortamlar kimi zaman askeri saha, kimi zaman askeri bölge olarak isimlendirilmiştir. Bu bölgeler her ne şekilde adlandırılırsa adlandırılsın sonuçta birer coğrafi alan oldukları gerçeğini değiştirmez. Bu coğrafi alanları, askeri coğrafya açısından tüm olumlu ve olumsuz yönleriyle birlikte askerî ve politik açıdan incelemek her dönem önem arz etmiştir. Sadece coğrafi koşulların veri ya da monografya şeklinde ortaya koyulduğu dönemlerde görülen eksikler neticesinde iç ve dış politikadaki kullanılan ve kullanması hedeflenen jeo'ya dayalı politikalar geliştirmek amaçlı olarak jeopolitikten de yararlanılmıştır. İki terimden de bilineceği üzere aynı havuzdan (mekân) beslendikleri görülmektedir. Askerî açıdan coğrafya ile daha çok verilere dayanan monografik çalışmalar ortaya koyulurken, jeopolitikte ise bu verilerden yola çıkılarak düşünce ve harekatın uygulanmasıyla ilgilenilmiştir. İki disiplinden faydalanılarak ortak şekilde düşünülebilir ve planlamalar yapılabilir. Küresel olarak askeri düşünce ve uygulama örnekleri incelendiğinde zaten stratejik gelişmelerden dolayı hem coğrafya hem de coğrafi mekânın politikası olan jeopolitiğin birlikte ele alınabildiği görülmektedir.

Gerek beşerî ve fiziki koşulları inceleyen askeri etüt çalışmaları gerekse askeri strateji neticesinde atlan adımlar her zaman bir mekân üzerinde olduğu için coğrafi bir nitelik taşımak zorundadır. Söz konusu lokasyon; topoğrafya, iklim, su, hava, toprak vb. bakımlardan farklı doğal özelliklere ve aynı zamanda hâkim sosyal ve kültürel sistemlere sahiptir. Bu özelliklerin bilinmesinin önemi, askeri coğrafyanın ortaya çıkmasına neden olmuş, bir coğrafya alt disiplini olarak; "askeri hedeflerin takip edilmesine yardımcı olmak için (hem fiziksel hem de insan açısından) coğrafi araşttrma araç ve tekniklerini uygulamaya" odaklanmıştir (Rech vd., 2015). Askeri coğrafya sadece savaş durumunda coğrafyanın etkilerinden değil, barış zamanında da askeri coğrafyanın verdiği bakış açısıyla çalışmalar yaparak coğrafyanın insana sunduğu olumlu ve olumsuz yanları tespit etmeye çalışmaktadır. Savaşların ve çatışmaların özellikle sanayileşme ve şehirleşmenin çok hızlı arttğı 20. yüzyılın başından itibaren tüm coğrafyaları doğrudan etkilediği görülmektedir. Savaşlar artı Orta Çağ kalelerinde, iki sınır arası boş bölgelerde, yerleşim alanlarından uzak arazilerde değil, şehirlerin dahil olduğu, askerî açıdan kara ve denizden sonra hava unsurları ile üçüncü boyutun eklendiği, bunun sonucunda insan ve mekânın doğrudan etkilendiği ortamlarda gerçekleşmektedir. Dolayısıyla gerek beşerî gerekse fiziki coğrafyanın, insan-mekân-zaman dahilinde savaş ve barış zamanında askerî faaliyetlere sunduğu olanakların incelenmesi gitgide önem kazanır hale gelmiştir. Coğrafi faktörlerin sadece olası savaşlar için askeri hususiyetler üzerindeki etkisi değil, aynı zamanda fiziki coğrafya (iklim, jeomorfoloji, topoğrafya, haritacılık, hidrografya vd.) ile beşerî coğrafyayı (nüfus, ekonomi, siyasi coğrafya, kültürel coğrafya, yerleşme, şehir coğrafyası vd.) birlikte ele alıp, askerî faaliyetlerin coğrafi ortam üzerindeki etkilerini savaşlardan bağımsız olarak da incelemektedir. 
Bu çalışmada kavramsal olarak askeri coğrafyanın tanımı, amaçları, tarihi gelişimi ile günümüz perspektifi ele alınarak askeri coğrafyanın coğrafi temellerdeki rolünün ortaya konması hedeflenmiştir. Çalışma boyunca askeri coğrafyanın, interdisipliner yaklaşım içerisinde temel bir inceleme alanı olarak, coğrafi ve jeopolitik açıdan askeri faaliyetler üzerindeki etkisi ve söz konusu mekâna katkısının tarihsel gelişimi üzerinde durulmuş, sonuç bağlamında askeri coğrafyanın bir coğrafi alt disiplin olduğu ve askeri çalışmalardaki öneminin giderek arttı̆ı ve artacağı sonucuna ulaşımıştır.

\section{Amaç ve Yöntem}

Bilimsel çalışmaların haber akışına, gündeme, politikaya, planlamalara ve ihtiyaca göre dönemsel olarak bazı konular üzerine yoğunlaştı̆ı bilinmektedir. Ancak birtakım konular vardır ki dönemsel yoğunlaşmanın aksine devamlı olarak önem arz etmesinden kaynaklı, incelemelerin ve çalışmaların ara verilmeden gerçekleştirilmesi gerekmektedir. Bu tür konuların başında da kuşkusuz hem barış hem de savaş ortamında devamlı düşünülmesi gereken askeri konular gelmektedir. Biz de bu çalışmamızla Türkiye'de coğrafyacılar tarafindan uzun süre ihmal edilmiş olan askeri coğrafyanın tanımı, kapsamı, inceleme alanı, sınırlılıkları ve amacını ortaya koyup sonrasında geçmiş ile günümüz tutum farklııklarının karşılaştırmasını yapmak için detaylı şekilde kaynak taraması veya belge incelemesi metotlarına başvurarak alana temel nitelikte bir yayım ortaya çıkarılması hedeflenmiştir. Ayrıca gerek coğrafi gerekse jeopolitik açıdan milli stratejiler ile hedefler geliştirirken askeri coğrafyanın öneminin ortaya konulması amaçlanmıştır. Dolayısıyla askeri coğrafya gibi ihmal edilmiş çalışma alanlarının incelenip özümsenmesi için tarihsel gelişiminin bilinmesi önem arz etmektedir. Bu çaIışmada gelişim sürecinin incelenmesi yöntemi dahilinde askeri coğrafyanın tanımı, kapsamı, sınırları ve gelecekteki muhtemel rolünün ortaya konulmasın gerekliliği üzerinden hareket edilmiştir. Bu gereklilik giderilmeye çalışılırken farklı ülkelerin askeri coğrafya üzerindeki etkileri, jeopolitik tasavvurları, benimsedikleri ekoller ve bunun askeri coğrafyanın gelişimi üzerindeki etkisi de göz önünde bulundurulmuştur. Daha önce bu şekilde bir çalışmanın yapılmamış olması bizim için çeşitli zorluk ve sıkıntilar oluştursa da sonrasında bu konuda yapılacak çalışmalara bu makalenin temel olabileceği düşüncesi olumlu etki yaratmıştır. Askerî konular ile ilgili bilimsel çalışmaların ve aynı zamanda askerî açıdan karar verme hususunda önemli rol oynayan bilimlerin (askeri coğrafya, askeri tarih, askeri sosyoloji vb.) üzerinde durulması oldukça önemlidir. Askeri coğrafyanın gerek tanımının ve kapsamının izah edilmesi gerekse Türkiye'deki gelişiminde ele alınan eserlerin neredeyse tamamı Cumhuriyet Dönemi'ne aittir ve askerler tarafindan yazılmıştır. Dolayısıyla alan üzerinde yapılan incelemeler neticesinde askeri coğrafya çalışmalarının (özellikle sivil coğrafyacılar açısından) eksik ya da tam olarak ele alınmadığı görülmüş ve bu konu üzerinde çalışma yürütülmesinin önem arz ettiği düşüncesiyle araştırma yapılması gerektiği ortaya konmuştur.

\section{Bulgular}

\subsection{Askeri Coğrafyanın Tanımı ve Kapsamı}

Bu alt alanda farklı zaman dilimlerinde farklı bilim insanlarının düşüncesini yansıtan askeri coğrafyanın tanımlamalarında da henüz net bir birlik sağlanamadığı açıkça görülmektedir. Uluslararası literatürde en çok kabul gören Lavallée, askeri coğrafyayı; genel ve stratejik operasyonlarda istihbaratının anahtarı olan zemin (fiziki coğrafya) ve coğrafi konum, ülkelerin kaderi, askeri, sanat ve stratejinin (beşerî coğrafyayı kastettiği düşünülmektedir) etkisini açıklayan alan olarak tanımlamaktadır (Lavallée, 1853). Ülkemizde ise en çok kabul gören tanımlama, askeri tarih ve coğrafya alanında önemli çalışmaları bulunan Tümerdem, (1939)'e aittir. Tümerdem'in ise askeri coğrafyayı; sevkülceyş (sevk: yollamak, ceyş: asker) ile arazi bilgisi yani strateji ile coğrafyanın harplere olan etkisini inceler (Tümerdem, 1939), şeklinde tanımladığı görülmektedir. Askeri coğrafyanın temel amaç ve hedeflerine atff yapan bu tanımda daha çok 20. yüzyılın ilk yarısındaki görüş olan, askeri faaliyetlere hizmet vurgulandığı görülmektedir.

Askeri coğrafya hakkındaki tanımlamaların yaşanan gelişmelerle birlikte çeşitli yıllara göre, dönemin şartlarına bağlı olarak değiştiği de görülmektedir. Çalık (1977) askeri coğrafyayı, genel coğrafyanın bir kolu olarak kabul edip bölgenin doğal ve beşerî coğrafyasının, ekonomik ve siyasi, stratejik durumlarının savaşın sevk ve idaresi üzerindeki etkilerini inceleyen bir dal olarak tanımladığı görülmektedir. İlerleyen yıllarda Görgülü, 1992 yılında yaptı̆̆ tanıma göre ise askeri coğrafyayı; coğrafi faktörlerin askeri faaliyetler ile askerî harekâtın sevk ve idaresi üzerine yapacağı olumlu ve olumsuz etkileri inceleyen, stratejik konularda coğrafi unsurlardan ayrı bir güç olarak istifade etmeye yarayan coğrafi disiplin olarak tanımlanmıştır. Ancak sonrasında tanımlamayı genişleterek taktik konularda, doktrin geliştirilmesinde çevrenin, coğrafyanın etkisini de incelediği ve genel olarak, askeri coğrafyanın istihbarat unsurlarına dayandığı, gerekli durumların belirlenmesinin yanında silahlı kuvvetler açısından ihtiyaçları ortaya çıkardı̆̆ını da dile getirmiştir (Görgülü, 1992). Görgülü ile Çalık'ın aslında eserlerinde benzer tanımları yaptıkları, farklı olarak Görgülü'nün tanım kapsamını biraz daha genişleterek askeri coğrafyayı, maksat ve hedefleri bakımından da incelediği görülmektedir. Dolayısıyla günümüz şartlarında bir tanımlama yapmak gerekirse ulusal ve uluslararası hedef, siyasa ve politika üretilmesinde katkı sağlayan askeri unsurlar üzerinde etkili fiziki ve beşerî coğrafya koşullarının insan-mekân-zaman süzgecinden geçirilerek askeri doktrin ve analiz geliştirmeye yarayan bilim alt dalına askeri coğrafya denilebilir. Sonuç itibariyle askeri coğrafyanın, tüm beşerî ve fiziki coğrafi unsurlarla birlikte bir bütün olarak ele alınması gerekliliği aşikardır. Harekât bölgesi analizi ve etütleri yapma konusunda oldukça önemli olan coğrafi koşullar içerisinde yer alan politik, askeri, sosyal, ekonomik ve teknolojik özellikler gibi beşerî coğrafya koşullarının, askeri coğrafya çalışmaları içerisinde yer alması oldukça önem arz etmektedir. Askeri coğrafyanın günümüzde, geçmişteki fiziki coğrafya özelliklerinin ağırlığına karşın hem beşerî hem de fiziki coğrafya özellikleri açısından ele alınması neticesinde hem coğrafyanın hem jeopolitiğin alt unsuru olarak üzerinde çalışabileceği de görülmektedir.

\subsection{Askeri Coğrafyanın İnceleme Alanı, Sınırları ve Amaçları}

Askeri faaliyetlerin sisteme, mekâna (kara, hava, su) ve şartlara (iklim, bitki örtüsü, arazi yapısı, savaş şartları, istihbarat, sevk ve idare, strateji ve benzeri) göre kendisini devamlı geliştirmesi gerekliliği askeri coğrafyanın da inceleme alanının ve sınırlarının genişlemesine neden olmaktadır. Özellikle de sadece fiziki açıdan bakmanın eksiklik oluşturduğunun gözlenmesi neticesinde beşerî yani insan faktörü açısından da konunun sınırlarının geniş̧letilmesinin doğru olacağı anlaşılmıştır. Ancak 
insan, yapısı gereği incelenmesi ve üzerinde çalışılması en zor olan canlı olmasından kaynaklı özellikle beşerî coğrafya kısmının konunun uzmanları tarafindan ele alınması gerekmektedir. Çünkü konunun uzmanı olmadan yapılamayacak kadar alt unsurlar (yerleşim alanlarının ekonomik, siyasi, politik, kültürel, askeri güçleri, nitelikli insan gücü, yeralt kaynakları, lojistik sistemleri, stratejik yolları, kent yapılanmaları, mevcut topluluğun nüfusu, dünya görüşleri, dini yapısı ve etnik durumu gibi tüm beşerî unsurlar) içermektedir. Ayrıca bir de zaman faktörünün de incelenmesi gerekliliğiyle birlikte içinden çıkılamaz bir noktaya gelebilmektedir. Kısacası askeri coğrafyanın inceleme alanı sanılanın aksine tüm coğrafyadır. İnsanın bulunduğu, bulunmadığı her alan savaşta ve barışta askeri coğrafyanın inceleme alanına girmektedir. "Insanlığın tarih sahnesinde yer almasıyla birlikte başlayan savaşlar; kazanmak için mekânın, başka bir ifade ile coğrafi yapının uygun kullanılması gereğini ortaya çıkarmıştır (Ucuzsatar, 1986). Mekânın (coğrafi yapı) savaş içinde oynadığı rolü ve insanların birbirleriyle olan mücadelelerde uyguladıkları taktik ve stratejik harekâtla olan ilgisini ve etkilerini askeri coğrafya incelemektedir.

Özellikle siyasi ve askeri rekabetin kuvvetlendiği 20. ve 21. yüzyılda, belirli güç boşlukları, terör odaklı tehditlerin ortaya çıkması ve jeopolitik dengesizlikler tekrardan askeri coğrafyanın kapsamını genişletmiştir. Bu anlamda özellikle kentler, stratejik hedefler, yoğun nüfuslu alanlar da askeri coğrafyanın inceleme alanı içerisinde kendisine yer bulmuştur. Askeri coğrafya zaman içinde çok genişlediği için belirli inceleme alanlarına ayrılmış ve sistematik olarak bölünmeye uğramıştır (Çoygun, 1960):

$\Rightarrow$ Genel Askeri Coğrafya: Dünya'nın, kıtaların ve ülkelerin coğrafi yapıları ile iktisadi bünyelerinin bir bütün olarak ele alınıp etüt edilmesidir. Sevk ve idarede kıtalararası, bloklar arası ve dünya savaşları çerçevesinde etkileri geniş olarak değerlendirilir ve sonuca varılır. İncelemeler, tekniğin ve gelişen teknolojinin ulaştırılacağı ortamlar çerçevesinde geliştirilmeli ve kapsamı gittikçe genişleyen mekân ile uyumlu olmalıdır.

$\Rightarrow$ Bölgesel Askeri Coğrafya: Genel askeri coğrafya konularını bölge bazında ele alır ve inceler. Örneğin; ülkenin coğrafi bölgelerinin, muhtemel savaşta harekât alanı olması halinde doğal ve beşerî coğrafi imkanlarının ve bunların münasebet ve derecelerinin incelenerek bir sonuca varılmasını (Çoygun, 1960) hedeflemektedir.

Çoygun aslında bu alt tanımlamalarla birlikte genel askeri ile bölgesel askeri coğrafya tanımını yapmış, genel askeri coğrafya konularının ele alış açısından bölge bazında incelendiği taktirde bölgesel askeri coğrafya yapılabileceğini söylemiştir. Ancak 17. yüzyılda bölgesel coğrafyanın temellerini atan Bernhard Varenius ve Vidal de la Blache, bölgesel coğrafyanın, sistematik yani genel coğrafya kuralları ile irdelenemeyeceğini, genel coğrafya kuralları ve ideaları geliştirirken, bölgesel coğrafyanın lokal olarak mekânı inceleyip daha fazla ayrıntiya inilmesi gerektiğini, konuyu etkileyen tüm faktörler ile konular arası bağlantıların kurulabilmesi gerektiğini ortaya koymuşlardır. Dolayısıyla kapsamı ve inceleme alanı olarak askeri coğrafya, bölgesel veya küresel düzeyde amacına uygun şekilde sistematik ya da bölgesel yaklaşımla yapılmalıdır. Bölgesel coğrafyanın metodolojisine uygun olarak yapılan askeri coğrafya araştır- malarının özellikle günümüzde daha yararlı olacağı da düşünülmektedir. Ancak tarihsel gelişiminde Çoygun'un da ifade ettiği üzere daha genel bakış açısına sahip dönemler olmuştur. Örneğin, "mekânı kontrol etme çabası içerisinde olan güçlü iktidarların askeri (military) coğrafya paradigması doğrultusunda işlevsel değerlerin rejim veya askeri güçler tarafindan tahakküm altnna alındığı" dönemler de olmuştur. (Özgen, 2010). Dolayısıyla askeri coğrafya uzun süre görevlerini yerine getirmek için askeri zümrenin başvurduğu coğrafi bilgiler olarak görülmüştür (Anderson, 1993). Ancak sanayi devrimiyle birlikte, insanın mekâna ve dolayısıyla da doğal ortama yönelik çeşitli yaptırımlarda bulunması, possibilist paradigmanın dayanağını oluştursa da (Özgüç \& Tümertekin, 2000), bu hususların etkilerini dünyanın her noktasında eşit zaman diliminde görmek imkansızdır.

Bu söz konusu askeri coğrafya çalışmaları yürütülürken direkt amaçlarının neler olduğu incelendiğinde ise;

1. Coğrafi faktörlerin askeri gücün kullanılması ve askeri hedefler doğrultusunda harekete geçirilmesine etkili olabilecek özelliklerini ortaya çıkarmak,

2. Coğrafi faktörlerin incelenmesi sonucu elde edilecek değerlendirmelerin ışığında, askeri gücün kuvvet ihtiyaçlarını tespit etmek,

3. Coğrafi şartların gerektirdiği biçimde silahlı kuvvetlerin eğitilmesini, teşkilatlanmasını ve teçhiz edilmesini sağlamak,

4. Askerî harekâtın zafere ulaştırılmasında coğrafyanın en uygun şekilde nasıl kullanılması gerektiğini belirlemek,

5. Coğrafi faktörlerden bir güç olarak istifade edecek esasları belirlemektir (Görgülü, 1992).

Bugüne gelindiğinde ise istihbarattan uzaktan algılamaya, insani faktörlerden uzay araştırmalarına kadar birçok alan ile doğrudan ilgilenmesi askeri coğrafyanın kapsamı açısından önemli bir adımdır. Buna bağlı olarak genel ve bölgesel ayrımlar yaparken, günümüze uygun ayrımlarla ele alınmalı ve coğrafyanın alt dallarıyla (hem beşerî hem de fiziki) birlikte askeri coğrafya incelemeleri sürdürülmelidir.

\subsection{Askeri Coğrafyanın Tarihsel Gelişimi}

Askerî harekâtın coğrafi bilgi gerektirdiği bilinen bir gerçektir. Bölgedeki mekân üzerinde kontrolün sağlanması ancak bölgenin fiziksel ve sosyal yapılarının bilinmesi neticesinde mümkündür. Bu nedenle organize harekât her zaman coğrafi bilgiyi ve coğrafyacıların sistemini, tekniklerini ve emeğini zorunlu kılmıştır. Hem askeri amaç ve hedefleri açısından hem de organize askeri teknolojilerinin gelişimi açısından savaş türleri gelişip değiştikçe, coğrafi bilgi türlerinin de değiştiği açıkça görülmektedir. (Woodward, 2009;2015). Askeri karar vermeyi desteklemek için coğrafi bilginin kullanılması, muhtemel olarak yazılı tarih öncesine dayanmaktadır. Askeri coğrafyanın ilk kullanımını Mısırlıların M.Ö. 1479'da Levant Bölgesi'ndeki savaş örnekleri verilebilse de bunun yeni keşiflerle daha da geriye gidebileceği unutulmamalıdır. Aslında tarih, içeresinde coğrafi faktörleri yorumlayan, kullanan ve etkilenen ünlü askeri liderlerin örnekleriyle doludur (Palka, 2011). Örnek vermek gerekirse Atinalı General Thukydides, Pelopponnes Savaşlarını (M.Ö. 431-404) anlatth̆ı eserinde savaşın üzerinde etkili olan 
çevresel ve beşerî faktörleri ele almış ve Thukydides zamanın jeopolitik ortamını iyi değerlendirerek polisler arası huzursuzluk, iç problemler, göçlerin yaratthğı sorunlar, ekonomik darlığın getirdiği problemlerin savaşa götürdüğünü, ordunun sevk ve idaresinin yeterli kalitede yapılamadığı için askerlerin dağıldığından bahsetmiştir. Antik Çağ ve sonrasında meydana gelen savaşlarda coğrafyanın rolü, mekânın insan ile zaman içinde olan etkileşimi coğrafya ve askeri faaliyetleri her zaman entegre hale getirmiştir. İnsanların askeri ve güvenlik problemleri dolayısıyla yüksek topoğrafyalara yerleşmesi, şehirlerini aşılması zor kaleler ile güçlendirmesi, sarp araziler tercih ederek savunmayı kolaylaştırmak gibi birçok unsur askeri faaliyetlerin coğrafya ile olan ilişkisini ortaya koymaktadır. Yaşadığımız topraklardan da örnek vermek gerekirse, Osmanlı Devleti 14. yüzyılın başlarında Marmara Bölgesi'ndeki birçok noktayı kontrol altına almasına rağmen Bursa'nın fethi için 6 Nisan 1326 tarihini beklemek zorunda kalmıştır. Osmanlı'nın, Bursa fethinin gecikmesinin nedenleri irdelendiğinde eski Bursa'nın yer aldığı bölgenin topoğrafyası yani fiziki coğrafyasından kaynaklandığı görülmektedir. Şehrin savunmasını kolaylaştıran bu durum Osmanlı'nın bölgeyi fethini geciktirmiştir. Hisar civarında 250-260 metre yüksekliğindeki plato yüzeyi, kalenin güney kısmının Uludağ tarafindan korunması ve traverten taraçalarının meydana getirdiği eğim, bölgeyi bir nevi fetih açısından ulaşılması zor bir alan kılmış ve dolayısıyla bölgenin ele geçirilmesi civar alanlardan sonraya sarkmıştır (Tuncel, 2020). Tıpkı bu coğrafi nedenlerden olduğu gibi, akarsu, vadi, dağ, çöller gibi diğer coğrafi şartlardan da devletler askeri faaliyetlerinde sık sık yararlanmıştır. Dolayısıyla resmî bir çalışma alanı olarak mevcut olmasa da askeri coğrafya antik zamandan beri kullanılmakta olan bir disiplin olarak karşımıza çıkmaktadır. Bunun sebebi her zaman coğrafyanın temelinde yer alan insan-mekân-zaman ilişkisinin varlığı ve insanın sürekli faaliyetleri ile dizayn ettiği mekanlarda zaman zaman askeri adımlar da atmasından kaynaklanmaktadır. Bu gibi durumlarda yukarıda bahsettiğimiz belirli kuvvet dengesini avantaja çevirmek amacıyla doğanın her türlü sunduğu faydadan yararlanmak askeri coğrafyayı önemli kılarken, aynı zamanda geçmişte insanın doğaya daha fazla bağımlı halde yaşar olması ve çevresel determinizmin kuvveti askeri coğrafyayı insan ile iç içe getirmiştir.

Resmî bir çalışma alanı olarak askeri coğrafya, 18. ve 19. yüzyılın başlarında Fransızlar, Almanlar ve İngilizlerin öncülüklerinde Avrupa'da ortaya çıkmıştır. 18. yüzyıldan itibaren de Batı'nın askeri düşünce sistemlerindeki yerini almıştır. Örneğin İtalya'da, savaş sanatlarında öğretilecek en önemli derslerden birisi olarak askeri coğrafya eklenirken, Fransa'da ise özellikle Almanya ile olan savaştaki yenilgiden sonra (1870-1871) askeri coğrafya, askeri okullarda subaylar için ders olarak eklenmiştir. Hatta Fransızlar söz konusu bu yenilginin başlıca nedeni olarak gördükleri coğrafi bilgi eksikliğinin giderilmesi adına halka ve askerlere bu yönde eğitimler planlamıştır. Sonrasında da ortaöğretim düzeyindeki çalışmalarda bile haritacılık ve jeopolitik odaklı yeni coğrafya müfredatı geliştirilmiştir (Salem, 2019). Avrupa ülkelerinin coğrafya ve askeri coğrafya konularının önemini önce kavraması ve bu yönde hızlı adımlar atması birçok savaşta (kendi içlerinde bile) diğer ülkelere nazaran avantaj sağlayan bir durum olmuştur.

Askeri coğrafya yayın açısından ele alındığında Theophile Lavallée'nin (1836) Géographie Physique, Historique et Militaire eseri yalnızca askeri coğrafyaya adanmış ilk yayın olarak kabul edilmektedir. İlgili alanda, bir yıl sonra Prusya Genelkurmay Başkanı Albrecht von Roon'un (1837), Avrupa'nın askeri bölgelerinin ayrıntılı fizyografik tanımlarını içeren bir çalışma yayınlamasıyla askeri coğrafya çalışmaları daha da ün kazanmıştır (Salem, 2019). Géographie Militaire eserinde Marga ise ekonomi, topoğrafik, kentsel, politik gibi konuların askeri liderler için önemini ifade etmiş (Marga, 1876) ve bu ifadelerde her zaman savaş alanı olan arazi kavramını incelemiştir. Öncelikle Avrupa'da daha yoğun bir şekilde askeri coğrafya ile ilgilenilirken The Influence of Seapower on History, 1660-1783 eseri ile Mahan (1890), ABD açısından alana geniş çapta kabul gören ilk katkıyı sağladı ve daha sonra stratejik coğrafya haline gelmesinin temelini att. Yirminci yüzyılın başında askeri coğrafya hakkında nispeten az sayıda ABD yayını olmasına rağmen, İngilizler, Maguire, Mackinder, MacDonell gibi isimler ile alana büyük katkı yapmaya devam etmiştir. Britanya'nın coğrafi alandaki olgunluğu sonraki yıllarda ABD perspektifleri üzerinde etkili oldu (Galgano \& Palka, 2012). Kraliyet Coğrafya Topluluğu'nun (RGS) 1830'daki organizasyonu ve 19. yüzyıldaki faaliyetleri, İngiliz Devleti'nin kolonyal operasyonlarının ayrılmaz bir parçası haline geldiği bilinmektedir. Hatta bu durum imparatorluğun genişlemesi için yararlı bir rehber haline gelmiştir.

19. yüzyılın sonlarında Oxford ve Cambridge Üniversitelerinde coğrafi eğitimin kurulması ile tanımlanan "Yeni Coğrafya", I. Dünya Savaşı'na kadar geçen yıllarda "Yeni Ordu" için pratik olarak yararlı bulunmuştur (Farish, 2009). Coğrafyanın yayılmacı anlayışa hizmeti Amerika Birleşik Devletleri'nde de farklı olmamıştır. 1818'de Amerika Birleşik Devletleri Askeri Akademisi West Point'te bir Coğrafya, Tarih ve Etik Okulu kurulmasıyla askeri coğrafyanın coğrafya ile olan ilişkisini anlamak ve geliştirmek için eğitimler verilmeye başlanmış, kısa süre içerisinde özellikle Monroe Doktrinini sonlandıran ve stratejik coğrafi alanlara hükmetmek isteyen ABD, II. Dünya Savaşı́na kadar askeri coğrafya alanında oldukça ilerleme kaydetmiştir. Dolayısıyla sömürgeci anlayış ve sanayi atlımları sonrası önemli kaynaklara gittikçe artan biçimde duyulan ihtiyaç, zamanla askeri coğrafyanın ortaya çıkışından, tanınması ve gelişimine kadar etkili olmuştur.

Özellikle I. Dünya Savaşı boyunca askeri faaliyetlerin üzerinde etkili olan coğrafi faktörlere oldukça dikkat edilirken, coğrafya adeta büyük askeri ve jeopolitik uygulamalarla güçlü ideolojik bir bilgi formu olarak kullanılıyordu (Hepple, 1986). Örneğin 16 Aralık 1940 yılında gerçekleştirilen Ardenler Taarruzu'nda Almanlar, bu karşı taarruz için müttefik hava kuvvetlerinin uçuşa çıkamadığı yağmurlu ve soğuk bir günde müttefiklerin önem vermediği arızalı ve ormanlık bir araziyi seçerek bir baskın niteliğinde saldırı gerçekleştirmiş ve bu beklenmeyen saldırıda cephe yarılarak 90 kilometre derinliğine ilerlenebilmiştir (Ucuzsatar, 1986). Bir başka örnek olarak da Dunkerque Tahliyesi gösterilebilir. Almanların, Dunkerque kıyılarında sıkışan 400 bin civarındaki İngiliz askerini imha etmesine kesin gözüyle bakılırken, Hitler yetkiyi iç çekişmelerden dolayı tank birliklerinden alıp hava kuvvetlerine vermiş fakat coğrafi şartları göz önünde bulundurmayan Almanlar, sisli bir günde hava kuvvetlerini efektif kullanamamaları sonucu ortalama 400 bin İngiliz askerinin 340 bine yakını başarıyla tahliye olmuş ve bu durum stratejik Müttefik zaferi sayılmıştır. Nazilerin sadece 
askeri coğrafyanın fiziki şartlarını değil, sınır jeopolitiğini, bölgelerin siyasi coğrafyasını, sosyal, kültürel ve etnik yapısı gibi konularını da kendi hakimiyet amaçlarının gerçekleşmesi için kullanması, savaş sonunda askeri coğrafya ve jeopolitiğin akademik dünyada önemli derecede taraflı olarak görülmesine sebep olmuş ve küresel dünyada bir düşüş ve ilgi eksikliği ile karşı karşıya kalmıştır.

Dolayısıyla tarihi gelişiminde II. Dünya Savaşı, askeri coğrafya için bir dönüm noktası olmuştur. Fakat sonrasında Soğuk Savaş'ın ortaya çıkması ve Amerikalı coğrafyacı Isaiah Bowman ve jeopolitik uzmanı Nicholas Spykman gibi isimlerin, Alman geçmişinden kurtarmak amacıyla jeopolitiği, demokratik ve küresel bir çalışma alanı olarak tanıtmak için çeşitli çalışmalar yürüttüğü bilinmektedir (Yeşiltaş, 2016). Dolayısıyla bu dönemde küresel güçlerin hakimiyet amacıyla geliştirdiği teoriler ve görüşler askeri adımlarda coğrafyanın etkisini ve haritacılığın önemini tekrar ortaya koyarken sonuç olarak coğrafyanın askeri yönü ve dolayısıyla askeri faaliyetler ile karar verme üzerindeki etkisi Soğuk Savaş boyunca da sürmüştür. Çalışmaların boyutları genişlemekle birlikte klasik askeri coğrafyanın izleri sahalarda hissedilmeye devam etmiş ve devletler daha önceki birikimlerini yeni sahalar üzerinde kullanmaktan çekinmemiştir. Başta beşerî coğrafya çalışmaları olmak üzere birçok coğrafi araştırma bat kaynaklı tehdide sebep olduğu düşüncesiyle birçok komünist devlet tarafindan ideolojik sebeplerle yasaklanmıştır. Buna karşın jeopolitik ve coğrafyanın askeri adımlarının, batıda rolünü artırarak devam etmesi ve teorilerin geliştirilmesi klasik dönemin devamı niteliğinde görülmektedir. Örneğin Nicholas Spykman, coğrafi özelliklerin dış politika üzerindeki en belirleyici etken olduğundan ve askeri faaliyetler ile coğrafi ilişkilerin öneminden bahsetmiştir (Spykman, 1938). Spykman'ın geliştirdiği Kenar Kuşak Teorisi, George Kennan'ın Çevreleme Politikası gibi politikalar devletlerin harita üzerinde, coğrafi temellere dayanarak askeri amaçlarını gerçekleştirmeye çalışması askeri coğrafyayı güncel tutan önemli olaylardır. $\mathrm{Bu}$ boyut askeri coğrafyanın genel durumunu oluştururken, ülkeler askeri faaliyetlerini sürdürdüğü sırada yerel bölgelerde de coğrafyadan yararlanmayı unutmamışlar, dolayısıyla askeri coğrafya daha geniş bir zemin kazanarak gelişimini sürdürmeye devam etmiştir. Örneğin 1970'li yıllarda Vietnam Savaşı'nda yaşanan bir örnekte de coğrafya ile askeri ilişkilerin devam ettiği açıkça görülmektedir.

Ağustos 1972'de Vietnam Savaşı'nda Amerika Birleşik Devletleri'nin, bir yıkım gerçekleştirmek amacıyla, Kızıl Nehir'in getirdiği alüvyonların taşkın yataklarını aşmaması için kurulan bentleri bombalaması ile yerleşim yerlerinin sular altında kalmasını hedeflemesi, coğrafi parametrelerin askeri faaliyetlerdeki bir kullanış biçimini gösterir. Bir savaşta askeri ve siyasi sonuçlar elde edebilmek için çoğu zaman toprakların, bitki örtüsünün, su kaynaklarının, bentlerin kullanıldığı görülebilmektedir ve ABD söz konusu faaliyeti ile stratejik ve gizli bir sıkıştırma ile zafer kazanmaya çalışmıştır. Bu yıkıcı eylemler yalnızca, bugün teknolojik ve endüstriyel savaş yoluyla belirli hedefler üzerinde uygulanan yıkım araçlarının istenmeyen sonuçları değil, aynı zamanda farklı unsurların zaman ve mekân olarak bilimsel uyumunu sağlayan kasıtlı bir stratejinin sonucudur. Amerika'nın yaptığı zoraki şehirleştirme ve köylerin yıkılmaya çalışılması buna örnektir (Lacoste, 2004). Ayrıca bölgeye yapılan bombardıman 3 yıl sürmüş fakat istenen netice alınamadığı için bölgenin fiziki coğrafyasına (ormanlık saha) uygun olarak gerilla savaşı yürütülmüştür (Armaoğlu, 2020). 1961'den 1968'e kadar ABD Savunma Bakanlığını yapan ve savaşta büyük rol oynayan Robert McNamara, Vietnam Savaşı'nı değerlendirdiğinde, bölgenin politik yapısını yanlış değerlendirdiklerini, dost ve düşman kavramlarını ayıramadıklarını ve mekânın tarihi, kültürü, siyaseti hakkındaki cehaletlerinin savaşta önemli rol oynadığını söylemiştir (McNamara, 2017).

Dolayısıyla bu ve bunun gibi örnekler neticesinde mekânın hem fiziki hem de beşerî yönlerinin, askeri faaliyetler ve başarılı stratejik analizler üretilmesi açısından ne kadar önemli olduğu görülmektedir. Günümüzde askeri coğrafya çalışmaları yapılırken sadece fiziki unsurların değil, aynı zamanda yukarıdaki örnekte de belirtildiği gibi insan faktörünün de zamana bağlı olarak tarihi, kültürü, görüşleri ve sosyal yapısının değerlendirilmesinin yanında bilimsel, teknolojik yeniliklerin de takip edilmesi önem arz etmektedir.

\subsubsection{Askeri coğrafyanın Türkiye'deki tarihsel gelişimi}

M.Ö. 201 yılında Mete Han liderliğindeki Asya Hun İmparatorluğu ile Han Çinlileri arasında Sangan-Ho ırmağının açtığı dar ve derin vadinin iki tarafinda kalan sarp ve dağlık bölgede gerçekleşen Çin Sındı̆̆ı Muharabesi'nde Türkler, Çinli askerleri Tatung-Fu'nun güneyinde (Datong Havzası yakınları, Kuzey Çin) Peteng yaylası gibi soğuk bir bölgeye çekerek iklimi avantaj olarak kullanmak istemiştir. Bunun neticesinde süvarilerden oluşan ordusunu bir süre geri çektikten sonra ortalama 240 bin kişilik Çin ordusunu uygun coğrafi alan oluşturarak imha etmeyi başarmıştır (Ucuzsatar, 1986). Böyle bir başarının aksine 1914 yılının kışında yaşanan Sarıkamış Harekatı́nda çok şiddetli iklim olaylarının ve zorlu fiziki koşullarına karşın ordunun giyecek ve teçhizatının azami olanaklarda sağlanamaması, mevsimin şiddeti düşünülmeksizin taarruz hareketinin yapılması ile lojistik konusundaki yetersizlikler, Türk ordusunun önemli bir kısmının zarar görmesine de neden olmuştur (Tümerdem, 1946). Dolayısıyla coğrafyanın askeri faaliyetlerde yeri geldiği zaman en kritik rolü üstlendiği kanısına ulaşmak çok da zor değildir.

Türklerde askeri coğrafya alanında ilk yazılı çalışmaya ise Osmanlı Dönemi'nde rastlanmaktadır. Osmanlı'da askeri coğrafya çalışmalarına, Avrupa ile benzer dönemlerde yani 19. yüzyıl başlarında rastlanırken, askeri coğrafya etütlerinin genellikle fetih amaçlı politikaların üretilmesinde coğrafyadan yararlanma amacıyla hazırlanmış eserler şeklinde olduğu görülmektedir. Bu eserlerin özellikle harp okullarının kurulmasından sonra subayların ihtiyacını karşılamak üzere üretildiği, ekonomi ve etnografya gibi konuları da ele alan eserler olduğu fakat sayı bakımından oldukça sınırlı düzeyde kaldığı bilinmektedir. Bu dönemdeki çalışmaları detaylı olarak inceleyecek olursak; Harp ve Erkân-ı Harbiye mekteplerinin müfredatında yer alan Coğrafya-yı Sevkülceyş, Stratejik ve İstatistikî Coğrafya, Topoğrafya, Teorik ve Pratik Coğrafya, Coğrafya-yı Askerî, Coğrafya-yı Sevkülceyşi ve Etnografya gibi derslere yönelik olarak benzer adlarla dönemin asker kökenli öğretmenleri tarafindan yazılan askeri coğrafya ana metinlerine ulaşabilmekteyiz (Çetin, 2019). Ancak Ahmed Cemal tarafindan kaleme alınan Memalik-i Osmaniye'ye Mahsus Coğrafya-yı Askerî (1892) adlı eser, isminde "askeri coğrafya" geçen ilk eserdir. Ayrıca Mehmed 
Tevfik'in birçok eserden istifade ederek sunduğu Coğrafya-yı Askerî ve Sevkülceyşi adlı eser de önemli bir çalışma olarak karşımıza çıkar (Çetin, 2019). Hüseyin Hüsni de aynı yıllarda askerî ve topoğrafya üzerine; Usûl-i Tahtît-i Arâzî'i Askerî (1880), Usûl-i Topografya (1882-1883), Mufassal Topografya Tatbikât (1886), Taksîmât-ı Düvel ve Müsta'merât-ı Mileli Hâvî Coğrafya-yı Umûmî ve Muhtasar Coğrafya-yı Osmânî (1894) gibi önemli eserler ortaya koymuştur (Üstüner, 2019).

Bu alan önceleri coğrafya ve jeopolitik düşüncenin birlikteliğiyle düşünülmüş hatta bazı dönemlerde jeopolitiğin alanı olarak görülmüştür. Ancak sonrasında coğrafyanın yarattğı etkilerin incelenmesi, coğrafyasız jeopolitiğin temelsiz kalmasından kaynaklı olarak 20. yüzyılın ilk yarısından sonra coğrafyanın bir alt dalı olarak döneme damgasını vurmuştur. Ancak askeri normların hâkim olduğu düşünce yapısında ilk dönemlerinde doğal olarak askeri coğrafya uzmanları hep askerlerden meydana gelmiştir. Türkiye'de de genellikle askeri tarih ile birlikte düşünülen askeri coğrafya, özellikle Cumhuriyet Dönemi'nde kendisine birçok eserle yer bulmuştur. Tümerdem (1939) Türkiye Askeri Coğrafyası, Sevkülceyş, Tabiye ve Harp Tarihi Bakımından Tetkik yine Tümerdem tarafindan 1942 tarihinde yazılan Türkiye Arazisini Operatif, Tabiye ve Harp Tarihi Bakımından inceleme gibi eserler örnek olarak gösterilebilir. Ayrıca askeri akademiler için çeşitli notlardan derlenen kitaplar askeri coğrafya literatürü açısından önem arz etmektedir. Askeri coğrafya, özellikle II. Dünya Savaşı'ndan sonra jeopolitik ve askeri coğrafyanın emperyalizmin hedeflerine hizmet ettiği düşüncesi, Friedrich Ratzel ile Karl Haushofer gibi coğrafyacıların "Lebensraum" adı altında jeopolitik hedeflerin Nazi Almanyası'nın kötü amaçlarına alet edildiği düşünüldüğü için sosyalist devletlerde beşeri coğrafyanın yasaklanması (Lacoste, 2014), Bat dünyasında bazı üniversitelerde coğrafya bölümünün kapatıması gibi önlemler alınarak göz ardı edilse de Türkiye'de askeri coğrafya ve buna ilişkin çalışmaların sürdürülmesine devam edilmiştir. Çoygun (Askeri Coğrafya; 1960), Çalık (Askeri Coğrafya; 1977), Ucuzsatar (Askeri Coğrafya; 1986), Görgülü (Askeri coğrafya; 1992) gibi eserler alanın temellerini en iyi şekilde yansıtan ve bölgesel coğrafya bakış açısı ile bölge ülkelerinin de askeri coğrafyası ile yakinen ilgilenen eserler olarak karşımıza çıkmaktadır.

Türkiye'nin bu dönemde bölgesel olarak askeri coğrafyasının incelenmesi sonucunda, askeri coğrafyanın diğer bilimlerle olan ilişkisinin ortaya konması, etüt formları ve metodolojik çalışmaların geliştirilmesi askeri coğrafyanın tarihsel gelişimine büyük katkıda bulunmuştur. Ancak o yıllardaki birçok eserde Prusya ekolünün Türkiye'yi de etkilemiş olduğu ve neredeyse tüm askeri coğrafya eserlerinde Carl Von Clausewitz'in düşüncelerine, fikirlerine yer verildiği ve yorumlanarak sentezler ortaya koyulduğu da görülmektedir. Dolayısıyla Türkiye'de askeri coğrafya eserlerinin bugünkü temelinde 19. yüzyıldan itibaren Türk ordusu üzerinde etkili olan Prusya ekolü (Uyar \& Gök, 2003) temsilcilerinin etkisi açık bir şekilde ortadadır. Fakat askeri coğrafya derslerinin sadece harp okullarında okutulması, sivil coğrafyacıların konuya dair ilgisinin ve çalışmasının neredeyse hiç bulunmaması ve dahi inceleme yapan insanların bazılarının coğrafyacı olmaması, alan üzerine yapılan çalışmaların coğrafya biliminin temellerine yayılmasını geciktirmiştir. Dolayısıyla sürekli jeopolitik ile pozitif olarak ilişkilendirilen ve sadece askeri amaçlara hizmet etmesi maksadıyla incelenen askeri coğrafya, bu açıdan dünyadaki örneklerinin aksine Türk coğrafyası adına daha daraltılmış bir alan olarak gelişimini sürdürmüştür.

21. yüzyıla gelindiğinde mekânsal analiz ve veri toplama işlemlerinin ilerlemesi ve bilgi sistemlerine entegre olması askeri coğrafyaya çağdaş bir bakış kazandırmış, Coğrafi Analiz Sistemleri (CAS) ile modern teknoloji, istihbarat ve coğrafi çaIışmalar yapılarak askeri faaliyetlerin coğrafi yönü temsil edilmeye başlanmıştır. CAS'ın sahip olduğu teknik imkânlar askeri karar verme sürecinin çeşitli adımlarında etkin olarak kullanılabilmektedir (Göztepe \& Akdağ, 2015). Askeri coğrafyanın ve faaliyetlerinin fiziki, sosyal, ekonomik vb. alanlara olan etkisi ile birlikte sivil coğrafyacılar ve jeopolitik düşünürleri de askeri coğrafya ile ilgilenmeye başlamıştır. Buradan hareketle Türkiye'de askeri coğrafya alanında literatür çok zengin olmasa da askeri coğrafyanın çağdaş standartlarda bir yapı kazandığı söylenebilir. Burada eksik olan konu, askeri coğrafyanın temel coğrafi bilimler ile entegresi, hala mevcut olan güncel literatür eksikliği ve belki de en önemlisi izole durumudur. İster coğrafya ister jeopolitik alanında olsun siviller tarafindan yapılan askeri coğrafya çalışmalarının halen çok eksik olduğu görülmektedir. Zaten ilklerden olacak olan söz konusu bu çalışmayla da eksikliğin bir ölçüde de olsa giderilmesi (alan tanım, kapsam, amaç, sınırları gibi kavramsal eksikleri ve tarihsel gelişimi açısından) hedeflenmiştir.

\subsubsection{Günümüz askeri coğrafyası ve neo-klasik tutumlar}

Askeri coğrafya kavramı üzerindeki tanımlamalarda teknoloji ve askeri coğrafyanın kapsamının genişlemesinin sonucunda tekrardan değerlendirme yapmanın gerekliliği aşikardır. Günümüz veya neo-klasik olarak değerlendirebileceğimiz askeri coğrafya, özellikle 21. yüzyıl teknolojisiyle birleşmesinden kaynaklanan yeni bir yapı kazanmış gerek coğrafi gerek askeri ve gerekse istihbarat çalışmaları açısından günümüzde önemini artırarak gelişimini sürdürmektedir. Değişen ve genişleyen yapısında askeri coğrafya artık sivil coğrafyacıların da önemli derecede ilgi gösterdiği, sadece askeri karar verme sürecini değil, askeri koşulların yarattğı tüm coğrafi etkiyi coğrafi bakış açısıyla araştırmaya başladığı bir zemin kazanmıştır. Bu açıya örnek vermek gerekirse "Militarizmin Mekânsallığı" önemli yeni bir kavramdır ve askeri coğrafyanın tarihsel gelişiminde de önemli bir yere sahiptir (Woodward, 2009;2015). Bu tarihsel gelişime bağlı olarak askeri coğrafyanın yeni yapısını kazanmasında bazı gelişmeler önemli rol oynamıştır. Sürece geçiş aşamasında yaşanan bazı gelişmeleri belirtilecek olursak;

- 1960 'ların sonunda Marksist siyasi teorilerin etkisinin coğrafya üzerinde azalmasıyla ortaya çıkan post-yapısal sürecin 1990'lar ile bir eleştirel yaklaşım ortaya çıkarması ve geleneksel askeri coğrafyanın değişime uğratılması (Rech, vd., 2015),

- Beşerî coğrafyanın betimleme yerine eleştirel yapı kazanması sonrasında mekânın militer yönlerine ve mekansallığına olan ilginin artması,

- Coğrafi ve toplumsal sorunlara yeni askeri yaklaşımların üretilebilmesi,

- Kültürel, sosyal, politik, ekonomik uygulamaların askeri yönünün görülmesi ve neticesinde bunun mekâna yansıtilması, 
- 21. yüzyıl başında güvenlik siyasetinin önemli boyut kazanması neticesinde savaşların tekrar alevlenmesi ve uygulamaların somut bir hal alıp küresel bir etki kazanarak coğrafi mekânı daha geniş anlamda etkilemesi,

- Askeri endüstri-ekonomi ilişkisi, gelişen silah menzilleri ile ülkelerin coğrafyasının tamamen tehdit altına alınmasıyla ekonomik olarak stratejik konumların tartışılması, toplumların ulus devlet inşası sonrasında sınır kavramını belirlemeye çalışması (Kapan \& Coşanar, 2020) ve sınır problemlerinin askeri boyut kazanarak bölgenin tüm beşerî ve fiziki coğrafyasının askeri perspektifte incelenme gereğinin ortaya çıkması (Kapan \& Yeşilbaş, 2021),

- $\quad$ Askeri faaliyetlerin ve kabiliyetlerin makro ölçekli hale gelip bölgesel coğrafya araştırmalarını daha önemli kılması gibi nedenler askeri normlar ile uygulamalı çalışmalar arasında bir ilişki oluşmasında ve yenilenmesinde etkili olmuştur.

Dolayısıyla klasik askeri coğrafya vizyonunun son 20-30 sene içerisinde ordu, teknoloji, küreselleşme üçlüsü doğrultusunda genişlediği ve yenilendiği aşikardır. Bu gelişmeler silahlı çatışma alanları coğrafyası, savaş ve barış coğrafyası, militarizmin coğrafyası gibi yeni ilgi alanları açmıştır ve çeşitli ülkeler belirli zaman dilimlerinden sonra çağdaş askeri coğrafyayı anlamaya ve onu kullanmaya başlamıştir. Örneğin Anderson'a göre Soğuk Savaş’ın sona ermesi ABD'deki askeri coğrafyayı yeniden canlandırmak için bir firsat sağlamış ve askeri unsurlar ile ilgili coğrafyaları kapsayacak şekilde genişletilmiştir (Anderson, 1993). Aynı zamanda teknolojik gelişmeler (bilgisayar destekli kartografya, GPS, GIS, hava fotoğrafçılığı vb.) ve dünyanın yeni güç dengesi göz önünde bulundurularak olumlu ve olumsuz yönde her an kullanılmaya çalışılmaktadır. Teknolojik gelişmelerle birlikte askeri faaliyetlerin hava gücü ile etki sınırının küresel özellik kazanması, modern askeri çalışmalar ile askeri coğrafya arasındaki ilişkiyi artırmış ve askeri coğrafyanın geleneksel bakış açısını değiştirerek genişletmiştir. Bununla birlikte insansız hava araçları, nükleer silahlanma ve nükleer teknoloji gibi askeri faaliyetlerin küresel zemin kazanmasını sağlayan gelişmeler de askeri coğrafyanın çağdaş yapısına önemli bir katkı sağlamıştır. Dolayısıyla devletlerin askeri adımlarını siyasi, ekonomik, teknolojik ve diğer yapılara yayarak sürdürmesi, coğrafi mekânın da bu faaliyetlerden daha geniş bir açıdan etkilenmesine neden olmuş ve askeri coğrafyaya çağdaş bir zemin kazandırmıştır.

Çağdaş ve klasik askeri coğrafya arasında belirli ilişkilerin yanında farklılıklar da söz konusudur. Bu konu askeri coğrafya ile kimin ilgilenebileceği veya ilgilenmesi gerektiğidir. Çağdaş dönemin öncesinde genellikle askeri coğrafyanın sivil coğrafyacıları kapsamadığı düşünülür. Örneğin Türkçe literatürde de çoğunlukla askeri coğrafyanın askeri bir bakış açısıyla işlenip, coğrafyanın tüm unsurlarını kapsayan fakat amaç olarak ondan farklı olarak düşünülürken, 20. yüzyıl sonlarına doğru yabancı literatürde de askeri coğrafyanın tarihsel perspektifinde çoğu zaman bu sanat ile ilgilenenlerin asker oldukları vurgulanmıştır. Örneğin Poole, eserinde gerçek askeri coğrafyacılar, arazi ve operasyonlar arasındaki ilişkiyi takdir eden ve gerekli ilişkileri sezgisel olarak kuran istekli ve genel olarak başarıIı askerlerdir şeklinde tanımlama yapar (Poole, 1944). Fakat kritik askeri çalışmalarda, ilgili sivil ve askeri ilişkiler, bu iliş- kilerin nüanslarının ve karmaşıklıklarının tanımlandığı, şeffaf, akademik ve askeri alanlarda paylaşılan bir eleştirel yaklaşım gereklidir. Bu nedenle askeri coğrafya gerek sosyal gerek doğa bilimleri açısından ilerici değişim amacıyla çaba gösterme firsatı sunmaktadır (Rech, vd., 2015). Askeri coğrafyanın modern yönünü aslında genişlemiş zemini oluşturur ve dolayısıyla askeri ilgi alanları, mekânın militarizasyonu ile yakından ilgilenir. Çağdaş yapısının buna göre belirlenmesi ve stratejik düşüncelerin genişleyen yapıya göre yenilenmesi son derece önemlidir. Dolayısıyla bir coğrafi bölgenin elde edilmesinden çok, bir coğrafi alanın askeri faaliyetlerden nasıl etkilendiği ve bundan gerektiği zaman nasıl yararlanılması gerektiğini araştırmayı amaçlayan bir disiplin haline dönüşmüştür.

Günümüzde askeri coğrafyanın, bir coğrafi bölgenin savaşların öncesi ve sonrasındaki etkilerinden çok daha fazlasını içeren zengin bir bütünleştirici olarak coğrafya ve jeopolitik ile birlikte düşünülmesi gerekmektedir. Bu iki geniş sınırları olan bilimlerin alt kümelerinden biri olmak demek, fiziksel, kültürel, siyasal ve toplumsal çevrelerin küresel, bölgesel ve yerel bağlamlarda her türlü siyasi-askeri ve coğrafi politikalarını, planlarını, programlarını ve muharebe/destek operasyonlarını askeri coğrafya üzerine yoğunlaştirması demektir (Collins, 1998). Bugün askeri coğrafyacılar bu kapsamlı süreci açıklamaya çalışmaktadırlar. Modern askeri operasyonların karmaşıklığı düşünülerek günümüz askeri coğrafyacıların, mekânı ve bunlar arasındaki bağlantıyı anlaması da bir o kadar zordur. Bu bağlantı noktalarını anlamak için askeri coğrafyacı, doğal ve beşerî alanın dinamiklerini ve süreçlerini, ayrıca bunların mekânsal ve zamansal kalıplarını anlamalıdır. "Çünkü tarih, bu faktörlerin belirleyici olabileceğini göstermiştir" (Galgano \& Palka, 2012). Askeri liderler, operasyonel ortamlarda kuvvet kullanmak ve savaşmak zorunda kaldıkları sürece, arazi, bitki örtüsü, iklim, hava ve insan manzarasının bilinmeyen ve değişken faktörlerini hesaba katmak zorundadır.

\section{Tartışma ve Sonuç}

Askeri coğrafya tüm unsurlarıyla birlikte coğrafyanın temelinden ve sentezinden ortaya çıkmış olup tüm askeri faaliyetlerin mekân ile olan ilişkisini ele alan coğrafi bir alt disiplindir. Ancak günümüzde gelişen ve değişen sistemler karşısında eskiden olduğu gibi tek bir husus üzerinden doğru sonuçlara ulaşmak zor görülmektedir. Bu noktada da tek disiplin ve tek bir grup ile uzman görüşüne sahip olmanın zor olduğu görülebilmektedir. Bu açıdan ele alındığında bir bölge ya da ülkenin askeri coğrafya açısından değerlendirilmesinde jeopolitik ve coğrafi unsurlar açısından ele almamanın büyük bir eksiklik olacağı aşikârdır. Günümüzde birden çok disiplin ve disiplin alt dalı ile ilişkisi bulunan askeri coğrafya için tek bir tanım altında buluşmak zordur. Ancak genel olarak ulusal ve uluslararası hedef, siyasa ve politika üretilmesinde katkı sağlayan askeri unsurlar üzerinde etkili fiziki ve beşerî coğrafya koşullarının insan-mekân-zaman süzgecinden geçirilerek askeri doktrin ve analiz geliştirmeye yarayan bilim alt dalına askeri coğrafya denilebilir. Söz konusu çalışmamızda askeri coğrafyayı tarihsel açıdan ele alıp amacı, sınırları, kapsamı, günümüzdeki durumu ve sorunlarının neler olabileceği üzerinde durulmuştur. Alan ile ilgili temel eksikliğin özellikle ilk yapılan çalışmalarda çokça sadece fiziki coğrafya konuları üzerinde durulduğu ancak sonrasında küreselleşme ve teknolojik gelişmeler neticesinde bu türde fiziki verilere gü- 
nümüzde daha rahat ulaşılmasından kaynaklı olarak bir bölge ya da ülkenin milli politikalar ve hedefler belirleyebilmesinde artkk beşerî özelliklerin üzerinde de durulduğu ve durulması gerekliliğinin tespiti yapılmıştır. Ancak insan, yapısı gereği incelenmesi ve üzerinde çalışılması en zor olan canlı olmasından kaynaklı konunun hem sivil hem de askeri uzmanlar tarafindan da ele alınması gerekmektedir.

Durağan bir yapının söz konusu olmadığı ve olamayacağı askeri faaliyetlerin, devamlı şekilde sistem, mekân ve şartlara göre kendisini geliştirmesi gerekliliği görülmektedir. İstihbarattan uzaktan algılamaya, insani faktörlerden uzay araştırmalarına kadar birçok alan ile doğrudan ilgilenmesi askeri coğrafyanın kapsamı açısından önemlidir. Bu örneklerden de hareketle 2021 itibariyle artık askeri coğrafya sadece sıcak çatışma bölgelerinde değil, bir coğrafi alanın askeri faaliyetlerden nasıl etkilendiği, etkileneceği ve bundan gerektiği zaman nasıl yararlanılması gerektiğini araştıran, planlayan ve uygulamaya geçiren bir disiplin alt dalı haline dönüşmüştür. Ancak insan faktörünün zamana bağlı olarak tarihi, kültürü, görüşleri ve sosyal yapısının değerlendirilmesi kesinlikle ihmal edilmemelidir. Bunun yanı sıra bilimsel, teknolojik yeniliklerin de sıkı takibi önem arz etmektedir. Ele alınan çalışmalara baktığımızda ise askeri coğrafyanın diğer coğrafya araştırmalarına göre daha az çalışıldığı görülmektedir. Bunun en önemli sebebi ise geçmişte askeri coğrafyanın sivil coğrafyacıları kapsamadığı görüşünden kaynaklandığı düşünülmektedir. Aslında bu görüşün 20. yüzyıl sonlarına kadar Avrupa'da da aynı şekilde olduğu bilinmekte ancak sonrasında sivil coğrafyacılar tarafindan da ele alınan ayrıntılı çalışmaların yapıldığı görülmüştür. Türkiye literatüründe ise halen askeri coğrafyanın asker kökenliler tarafindan işlendiği/ele alındığı görülmektedir. Ülkemizde de şeffaf ve uzman bir biçimde akademik ve askeri alanlarda iş birliği yapılarak eleştirel bir yaklaşım tarzıyla bu konunun ele alınması gerekliliği bulunmaktadır. Ülkemizde askeri coğrafyanın hem sivil hem de askerler tarafindan coğrafya, jeopolitik, tarih ve benzeri disiplinler açısından birlikte düşünülerek ortak bir çaIışma alanının oluşturulması gerekmektedir.

Askeri coğrafyanın özellikle jeopolitik ve tarih arasındaki ilişkiyle paralel olarak incelenmesi gerekliliği için tespite intiyaç yoktur. Askeri coğrafyanın tıpkı siyasi coğrafya gibi bir mekânın siyasi, askeri faaliyetlerden ne kadar/nasıl/ne şekilde etkilendiğini incelemek gibi bir olanağı varken, jeopolitikle de bir askeri güç olarak dış politikada unsurlarından yararlanılabilme olanağını bulunmaktadır. Askeri faaliyetlerin ve kabiliyetlerin günümüzde mikro alanlardan öte makro ölçekli bir hal alması coğrafi araştırmaları daha önemli kılmaktadır. Özellikle de eleştirel beşerî coğrafyanın saha ve veri çalışmaları konusunda sağladığı veriler ve teknolojik unsurların bu verilere entegreli olarak kullanılması askeri coğrafyanın güncellemesine/yenilenmesine katkı sağlayacaktır. Dolayısıyla askeri güç arayışı ile coğrafi bilgi arayışı arasındaki ilişki klasik askeri coğrafya anlayışından neo-klasik askeri coğrafya anlayışına geçebilecektir. Kısacası yenilenen ya da revize edilen askeri coğrafya alt disiplini daha kapsayıcı olabilecektir. Bölgesel ve küresel anlamda anlık güncel değerlendirmeleri de bize sunabilecek potansiyele sahiptir. Ancak elde edilen askeri tahlillerin, siyasaların, politikaların multidisipliner açıdan tekrar değerlendirilip bir sonuca vardırılması önem arz etmektedir.

\section{Kaynakça}

Akengin, H. (2019). Siyasi coğrafya. Insan ve mekân yönetimi (6. Baskı). Pegem Akademi.

Anderson, E. (1993). The Scope of Military Geography. GeoJournal, 31(2), 115-117. https://doi.org/10.1007/BF00808682

Armaoğlu, F. (2020). 20. yüzyıl siyasi tarihi (27. baskı). Kronik Kitap

Bruscino, T. (2020, Kasım 28). Military geography and military strategy. https://warroom.armywarcollege.edu/articles/geography-and-strategy/

Collins, J. M. (1998). Military geography for professionals and the public. Potomac Books.

Çalık, M. (1977). Askeri coğrafya ders notları. Harp Akademileri Basımevi.

Çetin, B. (2019). Tarihi coğrafya bakımından az bilinen bir kaynak: Anadolu-istatistiki, iktisadi ve askeri coğrafya (1. Cilt). Turkish Studies - Historical Analysis, 14(4), 785-805. https://doi. org/10.29228/TurkishStudies.37209

Çoygun, K. (1960). Askeri coğrafya. Kara Harp Okulu Teksir ve Yayın Bürosu.

Ekinci, D., Karabayır, S., \& Doğaner, S. (2015). Jeomorfolojik özelliklerin askeri strateji ve harp sanat üzerindeki etkileri. IV. Ulusal Jeomorfoloji Sempozyumu içinde, 418-440.

Galgano, F. A. \& Palka, E. J. (2012). Modern military geography. Routledge.

Göztepe, K., \& Akdağ, A. (2015). Coğrafi Analiz Sistemi (CAS) ile askeri karar verme süreci etkinliğinin artırılması. Harita Teknolojileri Elektronik Dergisi, 7(2), 56-68. https://doi.org/10.15659/ hartek.15.08.102

Görgülü, ì. (1992). Askeri coğrafya seri no:3. Harp Akademileri Basımevi.

Günel, K. (2002). Coğrafyanın siyasal gücü. Çantay Kitabevi.

Farish, M. (2009). Military and geography. In Rob Kitchin and Nigel Thrift (Eds.), International Encyclopedia of Human Geography, Vol. 7, (pp. 116-121). Elseiver.

Hansen, D. G. (1997). The immutable importance of geography. Parameters, 27(1), 55-64. https://press.armywarcollege.edu/parameters/vol27/iss $1 / 5$

Harmon, R. S., Dillon F. H., Garver, J. B. (2004) Perspectives on military geography. In Caldwell, D. R., Ehlen, J., Harmon, R. S. (Eds.), Studies in military geography and geology (pp. 7-20). Springer Science \& Business Media. https://doi.org/10.1007/978-14020-3105-2 2

Hepple, L. W. (1986). The revival of geopolitics. Political Geography Quarterly, 5(4), 21-36. https://doi.org/10.1016/02609827(86)90055-8

Illhan, S. (1989). Jeopolitik duyarlıık. Türk Tarih Kurumu.

Jackman, A. H. (1962). The nature of military geography. The Professional Geographer, 14(1), 7-12. https://doi.org/10.1111/i.00330124.1962.00007.x

Kapan, K., \& Coşanar, G. (2020). Sınır yerleşmelerine jeopolitik açıdan bakmak: Iğdır örneği. Ulisa: Uluslararası Çalışmalar Dergisi, 4(2), 175-197. https://dergipark.org.tr/tr/pub/ulisa/issue $/ 59274 / 851293$

Kapan, K., Yeşilbaş, N. (2021). Kura ve Aras Nehirlerinin Azerbaycan Aran (Kür-Araz) Bölgesi açısından jeoekonomik önemi. Avrasya incelemeleri Dergisi, 10(1), 167-192. https://dergipark.org.tr/tr/ pub/iuavid/issue/61114/907579 
Lacoste, Y. (2014). Coğrafya her şeyden önce savaş yapmaya yarar. Ayrınt Yayınları.

Lacoste, Y. (2004). Coğrafya savaşmak içindir. Doruk Yayımcılık.

Lavallee T. (1853). Géographie physique, hstorique et militaire. Charpentier Libraire Editeur.

Marga, A. (1876). Géographie militaire. E. Bourges.

McNamara, R. (2017). In retrospect: The tragedy and lessons of Vietnam, Vintage Books.

Military Geography (2020, 15 Aralık). https://geography.name/military-geography/

Okçu, Y. (1948). Askeri coğrafya notları, Yedek Subay Okulu Basımevi.

Özgen, N. (2010). Bilim olarak coğrafya ve evrimsel paradigmaları. Ege Coğrafya Dergisi, 19(2), 1-26. https://dergipark.org.tr/tr/ pub/ecd/issue/4872/66894

Özgüç, N. \& Tümertekin, E. (2000). Coğrafya: Geçmiş kavramlar. Coğrafyacılar. Çantay Kitabevi.

Palka, E. J. (2011). Military Geography in the US: History, scope, and recent developments. In Palka, E. J. and Galgano, F. (Eds.), Modern military geography (pp. 5-20). Routledge. https://doi. org/10.4324/9780203844397

Poole, C. S. P. (1944). The Training of Military Geographers. Annals of the Association of American Geographers, 34(4), 202-206. https://doi.org/10.2307/2561162

Rech, M., Bos, D., Jenkings, K. N., Williams, A., \& Woodward, R. (2015). Geography, military geography, and critical military studies. Critical Military Studies, 1(1), 47-60. https://doi.org/10.10 80/23337486.2014.963416

Salem, G. (2019). The educatin of military geography: between military sciences and human sciences (The case of the Lebanese Military Faculty). International Journal of Development and Economic Sustainability, 7(1), 49-65. https://www.eajournals.org/ wp-content/uploads/The-Education-of-Military-Geography.pdf

Spykman, N. J. (1938 Geography and foreign policy, I. The American Political Science Review, 32(1), 28-50. https://doi. org/10.2307/1949029

Spykman, N. J. (2020). Coğrafya ve dış politika kenar kuşak teorisi. Kürşat, A. (Çev.), Doğu Kütüphanesi.

Tuncel, M. (2015). Bursa'da Osmanlı fethini zorlaştran ya da geciktiren coğrafi nedenler. Şehir \& Toplum, (2), 7-11.

Tuncel, M. (2020). Şehir kuşatmalarında coğrafyanın rolü. İ̧̧inde Özkaya, A. S. (Ed.), Hunlar'dan günümüze Türk askeri kültürü, tarih, strateji, istihbarat, teşkilat, teknoloji (pp. 505-514). Kronik Kitap.

Tümerdem, H. (1939). Türkiye askeri coğrafyası, sevkülceyș, tabiye ve harp tarihi bakımından tetkik. Cumhuriyet Matbaası.

Tümerdem, H. (1942). Türkiye arazisini operatif tabiye ve harp tarihi bakımından inceleme. Resimli Ay Matbaası T. L. Şirketi.

Tümerdem, H. (1946). Türkiye süel coğrafyası Türkiye yereyini operatif tabiye ve harp tarihi bakımından inceleme (3. Baskı). Yedek Subay Okulu Matbaası.

Uyar, M. \& Gök, H. (2003) Modern Alman Ordusunun temelini teşkil eden Prusya askeri sisteminin kuruluşu ve olgunlaşması. Kara Harp Okulu Bilim Dergisi, 13(1), 1-28. https://www.academia. edu/13567377/Prusya Askeri Sisteminin Kurulu\%C5\%9Fu ve Olgunla\%C5\%9Fmas\%C4\%B1

Ucuzsatar, N. U. (1986). Askeri coğrafya. Harp Akademileri Basımevi.
Üstüner, A. (2019). Klasik Çağ sonrası Osmanlı coğrafya çalışmaları. Türkiye Araştırmaları Literatür Dergisi, 17(33), 41-104. https:// dergipark.org.tr/tr/pub/talid/issue/54143/731401

Yeşiltaş, M. (2016). Türkiye'de ordu ve jeopolitik zihniyet. Kadim Yayınları.

Yılmaz, S. (2015). Jeopolitik ve jeostrateji. İçinde Özdağ, Ü. (Ed.), Milli güvenlik teorisi (201-248). Kripto Basım Yayım.

Woodward, R. $(2009 ; 2015)$. Military geographies. In Kitchin, R., Thrift, N. (Eds.), International Encyclopedia of Human Geography, Vol. 7 (pp. 122-127). Elseiver. https://doi. org/10.1002/9781118786352.wbieg0280 